\title{
School Librarians in Action: A Comparative Study of School Library Programs in Croatia and Hong Kong
}

\author{
Annie Tam \\ The ISF Academy, Hong Kong \\ Anica Tkalcevic \\ XV Gymnasium, Zagreb, Croatia
}

King George V School, Hong Kong

Zvjezdana Dukic

University of Zagreb

\author{
Joy Xiaobing Zheng \\ Island Christian Academy, Hong Kong
}

\begin{abstract}
The study explores library programs in primary and secondary schools in Croatia and Hong Kong. The aim is to find what library programs the school libraries in Croatia and Hong Kong run in their schools, how these programs affect students' learning and what are similarities and differences between school libraries in Croatia and Hong Kong. The study findings show that school libraries on both locations run programs to support students' reading and to enhance their information literacy and research skills. School library programs in Croatia and Hong Kong include some similar components but also differ in some respects in approach and content. School librarians in Croatia involve wider community engagement while school librarians in Hong Kong apply technology for collection development and library instruction. Library programs in schools in both locations transcend the school walls and reach beyond the school curriculum as well.
\end{abstract}

Keywords: School Library Program, Croatia, Hong Kong, Primary School, Secondary School, Reading, Information Literacy, Collaboration, Technology

\section{INTRODUCTION}

Educational and instructional trends such as implementation of inquiry-based learning, collaborative approach to teaching and learning, learner-centered learning culture together with the implementation of modern technologies have significantly changed the role of libraries in school environment. School libraries become essential for teaching and learning and school librarians are getting more often engaged in performing various instructional duties. According to IFLA (2015) school librarians' instructional work involves literacy and reading promotion, media and information literacy instruction, supporting and guiding inquiry-based learning, integration of technology to teaching and learning as well as taking an active role in the professional development of teachers. School librarians are developing instructional components in their library programs, with emphasis on collaborative approach and application of modern technologies. The goal of modern school library is to support students' learning within school curriculum and beyond formal education system, learning any time and at any place. As school library programs differ from country to country due to differences in roles and status of school librarians (Lupton, 2016), comparative studies of school library programs in different countries will help us understand the functioning of school libraries in different environments and also may bring some new ideas to school librarianship practitioners. This study aims to explore library programs in primary and secondary schools in Croatia and Hong Kong and to find out how these programs support students' learning inside the library, across the school and beyond.

\section{LITERATURE REVIEW}

The literature on school libraries roles, programs and activities is abundant and as this study 
focuses specifically on school libraries in Croatia and Hong Kong we reviewed recent studies involving school libraries in the Croatian and Hong Kong context.

\section{Educational Roles: Reading support and information literacy instruction}

Modern school librarians play multiple roles in school environment. They are library administrators, collection managers and information specialists who provide access to library materials but they also teach skills required for using resources and communicating new knowledge ethically and effectively.

Many studies focus on educational roles of school librarians including students' enhancement of reading, information literacy instruction. Lo et al (2014a) examine roles of school librarians in Hong Kong, China, Taiwan, South Korea and Japan and find that school librarians in all five countries give priority to library reading programs.

A similar study has been conducted by Zorica and Dukic (2016) on a sample of primary school librarians' in Croatia and it was also found that school librarians gave priority to reading promotion programs, while teaching information literacy received less attention. It was also found that new technologies are rarely used for enhancement of library collections and services.

Chu et al (2008) examined how inquiry-based learning (IBL) affected students' reading and language abilities. Authors used a perceptual survey to detect students', teachers' and parents' opinions regarding improvement in student reading ability after the completion of an IBL, and suggested further investigations of the influence of instructional approach on improving students' reading.

Cheng (2012) researched school teachers' and students' perception of the functions and roles of teacher-librarians and found that most of the students and teacher participants were unfamiliar with the concepts of information literacy and information skills. Cheng also found that school library services were mostly related to books and reading.

In their study about the roles of school librarians as information literacy specialists, Lo, et al. (2014b) found that major reasons for Hong Kong students to visit the school library are still borrowing library resources and using library as a reading space. So, reading support is still perceived as library's primary function.

A study by Shu, et al. (2014) explored the educational role of primary school librarians in Hong Kong, Taiwan and Mainland China and found that school librarians in Hong Kong and Taiwan are more effective in developing students' information literacy and fostering students reading abilities. The author concluded that improvements are still needed and suggest to school librarians from Hong Kong to run workshops for teachers on implementation of information literacy to teaching.

Warning, et al. (2013) investigated the educational roles of primary and secondary schools teacher librarians in Hong Kong and found that their obligations to teach subject courses leaves them little time to provide library services and prepare and deliver library lessons.

\section{Collaboration with Teachers and Other Libraries}

Collaboration with teachers is an important component of school librarian's work and through collaboration with teachers school librarians demonstrate that their work helps to improve students' achievement (Cooper and Bray, 2011). Research shows that school librarians collaborate with teachers most often in reading promotion and developing library collections and less often in information literacy instruction (Lo et al, 2014b; Shu at al., 2014). Chu, et al. (2011) researched the impact of collaborative teaching on primary school students' information literacy and IT skills and concluded that good collaboration between school teachers and librarians had a positive impact on students' learning. Lai and Wei (2013) examined the integration of information literacy into the secondary school curriculum in Hong Kong and concluded that improvements are needed regarding librarians' and teachers' understanding how to develop information literacy program and how to work together on program implementation. Lo, et al. (2014b) researched information literacy instruction by school librarians in East Asian countries and found that Hong Kong teacher librarians most often teach IL skills separately from teachers, and only sometimes in collaboration with subject teachers.

School librarians are also encouraged to develop and implement library programs in collaboration with other libraries and cultural organization in the local community and in this way enrich their programs 
with new contents and activities (IFLA, 2015).

Stricevic (2008) researched the collaboration between school libraries and public libraries in Zagreb (Croatia). She found that the collaboration with local public libraries is most efficient when started and organized by school librarians as they are well acquainted with the situation within the whole school and are familiar with public library services as well.

\section{Using Technology and e-Resources}

Using technologies in school libraries is an important topic as school librarians are often expected to be technology leaders in their schools (Johnstone, 2012; Halverson \& Smith, 2009; Wine, 2016). Udina (2014) conducted a survey on technology use in school libraries in Croatia and found that school librarians use technology on a daily basis and for different purposes like providing information about library and its collections, circulation of library resources and email. From time to time they use technology for preparing library lessons, work with students and teachers and also for projects and team work. The conclusion is that school librarians use technology less often than expected, probably because of the lack of funds for equipment and also a negative response to technology be some teachers and some librarians.

A number of studies explored how acceptable e-books and e-readers are to library users in school and public libraries in Croatia. Milicki and Sudarevic (2016) researched primary school students' perceptions of reading e-books and found that majority of students still prefer to read books in print format. Although study participants are aware of many advantages of e-books such as easy access to ebooks any time at any place, easy text retrieval, links inside the text to other sources and making notes they state that they found reading from screen tiring and have difficulties in focusing on book contents. Milovcic (2012) investigated the use of various e-resources from the library webpage and found that teachers and students rarely use online resources. Also, many school librarians do not track e-resource usage and had no clue whether these resources were used or not. In the Hong Kong context there is a study by Ip, Chu and Sit (2008) that explored primary school students' reading habits of e-books and its correlation with their reading habits of printed books. Authors found that students who read more printed books also tend to read more e-books.

\section{RESEARCH QUESTIONS}

The main goal of this research is to explore school library programs in primary and secondary schools in Croatia and Hong Kong in order to find out how these programs meet the educational roles of school libraries and support students' learning.

To achieve these research goals the following research questions are formulated:

RQ1. What library programs are performed by school libraries in Croatia and Hong Kong and do these programs extend students' learning beyond the library walls?

RQ2. Are these programs performed solely by librarians or in collaboration with other school members such as teachers, IT staff, parents etc.?

RQ3. Are there differences in school library programs between school libraries in Croatia and Hong Kong?

\section{METHODS}

This qualitative study is aiming to explore library programs ran by schools in Croatia and Hong Kong. First we conducted an interview for data collection. Purposive sampling technic was applied and participating schools were selected. Interviews were conducted with school librarians from five schools on each location. Sample sizes are small, which is typical for qualitative research.

The Hong Kong sample includes three secondary schools (one bilingual private school with the IB curriculum, one international schools with the IB curriculum and one local school following the Hong Kong curriculum), and two primary schools (one small Christian school with the British curriculum and one bilingual private school following the IB curriculum). Croatian sample consists of three secondary 
schools (two gymnasiums and one school with five different streams) and two primary schools. Schools from Croatia all follow the Croatian school curriculum.

Collected data were analyzed by applying thematic analysis (Braun and Clarke, 2006). Interesting features of the data were systematically coded across the entire data set and major themes were defined. Finally, all data were arranged under broader themes in a way that all data belonging to the specific theme were brought together.

This empirical research has been conducted on two geographical locations: Croatia and Hong Kong and the research team consisted of researchers from both locations. Researchers from Croatia and from Hong Kong communicated regularly through email and Skype.

The limitation of this study is that, due to its small sample, its research findings and conclusions cannot be readily generalized to a wider population of school libraries in Croatia and Hong Kong. On the other hand the findings may be very helpful to researchers in developing quantitative studies on larger samples that would secure generalizability of results and extend the knowledge of school library programs.

\section{DATA ANALYSIS AND DISCUSSION}

School library programs in Croatia and Hong Kong are mainly focused on two major educational tasks. One task is enhancing students' general literacy and developing reading habits, whereas the other task is developing students information literacy and research abilities. Before starting the analysis of the collected empirical data it would be important to point out to some differences between Croatia and Hong Kong regarding the school educational system that may influence the library programs. While in Hong Kong the primary school lasts six years, in Croatia it takes eight years of education. Furthermore, children in Hong Kong start primary school at the age of six in local schools and at the age of five in international schools, while in Croatia children enter primary school at the age of seven. Secondary schools in Croatia last four years and enroll student at the age of 15 while in Hong Kong secondary school takes six years (local schools) or seven years (international IB schools) and students' enrollment age is around eleven. Therefore, school library programs in Croatia have to cover a longer time period for primary schools and a shorter period for secondary schools.

Although library programs for primary and secondary schools, both in Croatia and Hong Kong, may have some similar components they still differ significantly and for this reason they will be analyzed and discussed separately.

\section{Reading Support Programs}

Empirical data about reading programs in primary schools in Croatia and Hong Kong were organized in four sub-themes (Tables $1 \& 2$ ). The fist sub-theme involves regular reading support activities and the second is about special events. In the third theme the Croatian and Hong Kong schools slightly differ as local empirical data influenced the defining of sub-themes. For Croatian primary school libraries the third theme is participation in reading projects while for Hong Kong primary schools it is about contests related to books and reading. Findings show that primary schools in Croatia and Hong Kong promote reading through suggested readings, book displays and various reading activities. Schools in Hong Kong are subscribed to some reading and storytelling platforms and actively promote them in library sessions. School librarians on both locations organize, sometimes in collaboration with teachers, some special school-wide events such as invited talks by children's authors and some special reading activities. Hong Kong primary school librarians organize Book-week once a year, a week-long whole school engagement in reading and many reading-related activities.

Table 1. Reading programs in primary school libraries in Croatian

Regular reading support activities

- Book displays, posters about books and authors, book quizzes, reading aloud and reading together: forgotten books, under the stars, my teacher's favorite book, reading to first graders 
Special reading events

- Book study - reading in costumes, watching movies, workshops

- Bookmark exchange project (in collaboration with geography teacher)

- Invited talks: writers, poets, illustrators

- Workshops for parents about library and reading

- Visits to the local public library

Participating in reading projects on the state level

- Reading backpack - a traveling backpack with 8 books for the whole family

- $\quad$ Party with letters - overnight with reading activities (7 pm-7 am )

- Reach for the stars with reading - reading contest - 3 books read and quizzes

- Book night -celebration of the World Book and Copyright Day - activities involving libraries, bookshops, publishers, museums and theaters, etc.

Reading support on the library webpage

- Picture-books in Croatian and English

- E-books - prescribed and free readings

- International Children's Digital Library

Note: Some reading activities above are performed in collaboration with teachers

The third sub-theme is particularly interesting for both the Croatian and Hong Kong primary school libraries. Listed activities point to collaboration among primary school librarians in organizing and running those events. Croatian school librarians encourage students to actively participate in various reading projects organized by local library associations such as Reading backpack, Party with letters and Reach for the stars with reading. They also take students to various programs during the Book night, the event co-organized by various organizations dealing with books, reading and literature. These projects are often run in collaboration with school teachers. For school librarians in Hong Kong the dominant activity in this sub-theme is the inter-school competition Hong Kong Battle of the Book which involves a yearlong preparation for students with reading and weekly practice activities.

Table 2. Reading programs in primary school libraries in Hong Kong

Regular reading support activities

- Book displays, reading lists, book talks, reading aloud (by librarians, teachers \& parents volunteers)

- Guiding students how to use e-platforms for reading and storytelling

- Tumble Books - a storytelling website with quizzes, activities, lesson plans

- Follett e-books collection

- Teaching literary genres - planned in collaboration with teachers

- Ordering guided reading books in collaboration with English coordinator

- Book-club - older students help organizing reading activities and games

Special reading events

- Authors and storytellers school visits

- Book week - reading activities: Drop-everything-and-read, book character day, guess who is reading, etc.

- Bookmark exchange project

Contests related to books and reading

- Hong Kong Battle of the Book - inter-school reading contest - students read 20 books and 
compete in teams of 5 (answer questions about the books)

- Book trailer contests - students make book trailer in iMovie

- Reading champions - students who borrowed the most books in a month

Reading support on the library webpage:

- E-books and storytelling platforms: Tumblebooks, Follet e-books

- E-books from HKPL, free e-books from the Internet (English \& Chinese)

- Audible books

- Book Adventure - reading program (book quizzes and reading progress tracking)

- Reading support websites: Bookhive, Kidsreads, Boys Blokes Books, Kids Book Review, RIF Kids Reading Planet

- Learning tools for digital poetry writing and digital storytelling

Note: Some reading activities above are planned in collaboration with teachers

The fourth sub-theme is the reading support online. Primary school librarians in Croatia and Hong Kong encourage students' reading by posting various reading materials on the school library webpage. Croatian school librarians provide some online reading resources, like a selection of e-books for free reading and prescribed reading, digital picture books in Croatian and English and access to International Children's Digital Library $(I C D L)$. School librarians from Hong Kong offer rich collections of various electronic reading materials, some subscription-based and many available for free from the Internet. Besides many e-books, there are various educational websites where students can learn about children's literature. There is also a well known Book Adventure reading program with book quizzes, reading tracking system and prizes. It can be concluded that Croatian primary school librarians use information technology in their reading programs a little less then librarians in Hong Kong primary schools. This finding is not a surprise since studies from Croatia indicate that technology and e-resources are not very popular among students and teachers (Milovcic, 2012; Udina, 2014; Milicki and Sudarevic, 2016) while a study from Hong Kong (Ip, Chu and Sit, 2008) finds that e-books are well accepted among primary school students. It is interesting that Jones and Brown (2011) also found that book theme, characters and preferences of readers were far more important to young readers then the format in which the book was delivered. In view of the collaboration between school librarians and teachers it can be concluded that primary school librarians in Croatia and Hong Kong have a good collaboration with teachers in running school library reading programs and activities.

Study findings about reading programs in secondary schools in Croatia and Hong Kong show that school librarians on both locations are highly engaged in promoting reading to students and organize various reading related activities inside the library, school-wide and outside their schools (Table3 \& 4). Empirical data are organized in three major subthemes: Regular activities inside the library, Special events and activities and Reading support on the library webpage. Reading programs in secondary school libraries in Croatia differ in all three sub-themes. Regular activities inside the library for Croatian school librarians include book displays, lists with suggested readings, invited talks, movie watch, workshops, reading and library clubs and reading sessions. Besides program activities inside the school Croatian secondary school librarians, often in collaboration with teachers, organize some special events and activities. They organize group visits to other libraries and various cultural organizations, bring students to talks or shared reading sessions in local public library and encourage students to take part in various events related to books and reading taking place in their local environments. Croatian secondary school librarians also run some community projects, like visiting local home for elderly for reading aloud together and collecting books for donations.

\section{Table 3. Reading programs in secondary school libraries in Croatia}

Regular activities inside the library

- Reading lists (including popular science books), students' wish lists, lists of new arrivals with annotations, book displays - authors, themes, important dates and events, (in 
collaboration with teachers)

- Invited talks and round tables with writers, actors, scientists, other experts

- Watching movies based on novels

- Workshops (collaboration with teachers and other organizations): 3-D printing, book repair, Glagolitic calligraphy and silk painting

- Clubs and reading sessions

○ Reading club - monthly reads;

- Library club - boor repair

○ Reading aloud together (e.g. Croatian poetry)

Special events and activities - group activities outside the library (often in collaboration with teachers):

- Visits to public, national and university libraries, museums, archive, historical and cultural memorial places, exhibitions, book fairs

- Attending talks in the local public library (e.g. What is Jazz? Studying in USA)

- Reading aloud together (students, teachers, others) in the local public library

- Active participation in book and reading events (city or state level):

- Book noises -in collaboration with National and University Library

- Inter-liber-book fair - round table and workshops for students

- Croatian Book Month - includes various literary activities

- Book night-celebration of the World Book and Copyright Day-organized by libraries, bookshops, publishers, museums, theatres, etc.

- Community projects:

$\bigcirc \quad$ visiting the local home for elderly and reading aloud

$\circ$ collecting books for donations

Reading support on the library webpage:

- E-books

- ICDL

- Audio books

- Croatian writers

Secondary school librarians in Hong Kong also run various regular reading programs inside a library and school-wide, such as creating various reading and resource lists, arranging book displays and promoting awarded books. Furthermore, they encourage students' reading by using borrowing tracking system and electronic reading program with quizzes. In collaboration with school librarians in other secondary schools in Hong Kong they organize voting for Hong Kong librarians' literary award.

Special events and activities include the Book-week which is rich with various activities for students including inviting famous authors, scientists and other interesting speakers to give talks. They also organize in-school and inter-school reading competitions which engage students through the whole school-year, again in collaboration with school librarians from other schools in Hong Kong.

\section{Table 4. Reading programs in secondary school libraries in Hong Kong}

Regular activities inside the library

- Reading lists (Chinese and English books), resource lists on various teaching topics, book displays in the library and in OPAC, promoting awarded books from Carnegie Medals, ALA award, Man Booker Prize \& Nobel Prize

- Voting for book awards - Hong Kong Golden Dragon Book Awards - in collaboration with school librarians in HK

- In-house book borrow tracking system: tracks borrowing, inlcudes various activities and 
awards of merits for students

- Managing Accelerated Reader - online reading monitoring program with quizzes

Special events and activities

- Book-week (in collaboration with teachers): hosting a book fair, DEAR time, Book character dress-up day, authors' visits, etc.

- Organizing school visits by famous writers, academics etc.

- Attending events at Hong Kong International Literary Festival

- In-school reading contest - The Battle of the Book (involves weekly practices)

- Inter-school reading contests (collaboration with school librarians in HK)

- Hong Kong Battle of the Books - competing with schools in HK

○ Kids Lit Quiz

Reading support on the library webpage:

- E-books (subscription based and free from the Internet)

- E-book collections from the Hong Kong Public Libraries

- Reading based social networking tools: GoodReads, Pinterest

Regarding the support of reading through digital collections, findings show that secondary school librarians in Croatia and Hong Kong provide online access to e-book collections. School librarians from Hong Kong also use electronic tools to promote books and reading to their students, a reading stimulation program Accelerated Reader and some reading dedicated social networking tools, such as GoodReads and Pinterest.

Although reading programs in secondary school libraries from Croatia and from Hong Kong have some similarities they also differ, particularly in activities spread out to the wider community. While secondary school librarians from Hong Kong focus more on reading itself and collaborate in some programs with other school librarians, Croatian school librarians extend their reading programs to various cultural events and connect with the local community. This extended perspective on reading and related activities of school librarians from Croatia is probably influenced by norms for school libraries prescribed by Croatian Ministry of Education which defines the roles of school libraries as educational, professional and cultural (Zakon o Knjižnicama, 2009). Anyway, the study findings confirm that a collaboration with teachers, other librarians and specialists from various cultural organizations is an important component in library programs realization for school librarians both in Croatia and Hong Kong (Tables 3 \& 4).

To summarize, the findings about reading programs for both primary and secondary schools, in Hong Kong and in Croatia indicate that school librarians pay great attention to reading promotion and provide a wide span of activities to engage students in reading more. This observation coheres with the results from empirical studies about the various roles of school librarians in Croatia and Hong Kong (Lo at al., 2014b; Zorica and Dukic, 2016). Further, it can be concluded that Croatian and Hong Kong school librarians widely extend school library reading programs outside the school walls.

\section{Library Instruction Programs}

Research findings about library instruction programs indicate that primary school libraries from Croatia and Hong Kong contribute to the development of students' information literacy (Table 5 \& 6). Data are coded under four sub-themes: Library guidance and instruction, Other instructional activities, Instructional materials on Moodle and Collaboration with teachers.

Librarians from Croatia and Hong Kong provide library orientation, instruct students how to search library OPAC and how to find resources in the school library. While primary school librarians from Croatia cover the use of various information sources (reference, periodicals and the Internet) and copyright issues, Hong Kong librarians teach the whole research process by using the Big6 model. Hong Kong librarians pay special attention to information retrieval of electronic resources.

Table 5. Library instruction in primary schools in Croatia 
Library guidance and instruction:

- Library orientation (students and teachers)

- Searching OPAC and locating resources in the library

- How books are made: from writing to publishing

- How to use encyclopedia, dictionary, Internet, periodicals

- What is copyright

Other instructional activities

- Workshops on using digital tools:

○ Creating picture books and cartoons: Photostory, Storybird

- Entrepreneurship - learning about the concept, attending the workshop for making pocket diaries, making pocket diaries in school and selling them at the school Christmas fair

- Financial literacy - lessons by university students in Economics

- Civil education - volunteering and team work

○ Visiting local homes for elderly - reading to elderly

$\circ$ Visiting hospitals - reading to sick children

- Bible lessons

Instructional materials on Moodle

- types of libraries

- how to find information

Collaboration with teachers

- Share ideas how to include school library to curriculum

- Lists of readings for teachers' professional development

- Support teachers' lessons with guidance in using library resources

- Strong support by school principle, good collaboration with teachers

Primary school librarians in Croatia organize some other instructional activities with students such as workshops on creative use of various digital tools, lessons on financial literacy (in collaboration with university students of Economics), entrepreneurship, and civil education. Primary school librarians from Hong Kong run workshops for parents and train students as library helpers. Hong Kong librarians use the school Moodle platform for library instruction more extensively than school librarians in Croatia. Regarding the collaboration with teachers study findings show that primary school librarians both in Croatia and Hong Kong provide library instruction by working together with school teachers. School librarians also support teaching and learning in other ways (Table $5 \& 6$ ).

Table 6. Library instruction in primary schools in Hong Kong

Library guidance and instruction

- Library orientation (students and teachers)

- Searching OPAC and locating resources in the library

- Retrieving electronic resources

- Big6 research skills: 6 stages in the research process

- Citation and referencing

- Literary genres and author study (to support class teaching)

Other instructional activities

- Workshop for parents

- Training students library helpers: Circulation Officer, Shelf Elf (shelving duty) 
Instructional materials on Moodle

- All English library lessons

- Bibliographic tools

- Guidance for using search engines

- Media reviews

- Resources for parents: how to use OPAC, notes from library talks, how to encourage reading

Collaboration with teachers

- Suggest resources for teaching

- Plan and teach library lessons with teachers

- Collaborate only with some teachers

It can be concluded that primary school libraries on both locations provide significant input to students' learning beyond library walls. While school librarians in Hong Kong are more focused on the research processes Croatian school librarians are more open to other instructional areas and spread their collaboration to people and organizations outside their school.

Instructional activities focused on developing students' information literacy and research ability in secondary school libraries in Croatia and Hong Kong are organized in five sub-themes: Library orientation, Information literacy topics, Other instructional activities, Tutorials on school library webpage (or Moodle) and Collaboration with teachers (Table $7 \& 8$ ). School libraries on both locations provide library orientation for new students and teachers. The information literacy topics covered in library lessons conducted by Croatian and Hong Kong secondary school librarians differ slightly, as librarians from Hong Kong base their instruction on the Big6 research skills scheme and focus more on electronic resources retrieval and evaluation. This aspect of information literacy is of great importance for Hong Kong students as they have access to numerous electronic resources either through school's own subscriptions or through Hong Kong Public Libraries. Unfortunately, school libraries in Croatia do not have this privilege and mostly do not have access to electronic databases. Citation and referencing is covered by both Croatian and Hong Kong information literacy programs. Information literacy classes are designed to help students to apply information literacy skills to complete their specific assignments or projects. School librarians in Croatia extend their library instruction to some other topics that may enhance students learning, such as how to create a good presentation, improving students' writing skills, media literacy and civil education.

Table 7. Library instruction in secondary schools in Croatia

Library orientation (for new students and teachers)

- OPAC, collections, services, introducing school library webpage

Information literacy topics

- Use of various sources of information

- Reference collection - encyclopedias, bibliographies, portals

- Periodicals

- Citation and referencing

- Creating presentations (poster, PowerPoint)

- Writing skills

- Workshops in collaboration with teachers: exploring topics by using various information sources (e.g. planet earth day, Renaissances)

Other instructional activities:

- media literacy (understanding commercials), civil education 
Tutorials on school library webpage:

- Call numbers, classification system

- Citing and referencing

- Safety on the Internet, Netiquette, Facebook privacy

Collaboration with teachers

- Workshops

- Arranging teaching sessions

Secondary school librarians in Hong Kong teach information literacy by using school Moodle and by posting various instructional materials on the school library website or on the Moodle platform. School librarians in Croatia put very few instructional materials on the school library webpage. All in all, secondary school librarians in Hong Kong use technologies more extensively for supporting teaching and learning.

Table 8. Library instruction in secondary schools in Hong Kong

Library orientation (for new students and teachers)

- Searching OPAC and locationg resources in the library (DDC)

Information literacy topics (Teach with Moodle):

- Big6 research processes

- Database retrieval

- Evaluation of sources

- Academic honesty and citation

Other activities

- Visits to other organization to listen talks (e.g. local universities)

- Workshops for parents

Tutorials on school library website (Moodle Library page):

- Research skills

- Bibliographic and citation tools

- Databases user guides

- Online students' bulletin - book renewal

Collaboration with teachers

- Design the lessons together with teachers

- Teach in collaboration with Humanities and English teachers

Further, secondary school librarians in Croatia and Hong Kong collaborate with teachers in performing instructional activities. They plan lessons with teachers, sometimes teach together or run thematic workshops for students together but the collaboration depends very much on teachers' schedules and the willingness of individual teachers to collaborate with school librarian. This finding is similar to the results from research on school librarian-teacher collaboration in Croatia (Zorica \& Dukic, 2016) and Hong Kong (Lo, et al., 2014b) showing that secondary school teacher librarians only occasionally collaborate with teachers in information literacy instruction.

Table 6. Barriers to organizing library programs in Croatian and Hong Kong schools

\begin{tabular}{|l|l} 
Primary school libraries in Croatia & Primary school libraries in Hong Kong
\end{tabular}




\begin{tabular}{|c|c|}
\hline $\begin{array}{l}\text { No barrier } \\
\text { - Strong support by school principle } \\
\text { - Good collaboration with classroom and } \\
\text { subject teachers }\end{array}$ & $\begin{array}{l}\text { - Lack of lesson time } \\
\text { - School principle doesn't recognize } \\
\text { librarian as a teacher } \\
\text { - Insufficient professional development } \\
\text { - Lack of staff and funds }\end{array}$ \\
\hline Secondary school libraries in Croatia & Secondary school libraries in Hong Kong \\
\hline $\begin{array}{l}\text { - } \\
\text { - } \quad \text { No timetable for library lessons } \\
\text { - } \quad \text { Library instruction depends on librarians' } \\
\text { good will } \\
\text { - } \quad \text { Lessons are organized by using form } \\
\text { tutor's classes, after school, in the } \\
\text { evening, classes of subject teachers and } \\
\text { open teaching day } \\
\text { - Lack of staff and lack of space for big } \\
\text { groups' activities }\end{array}$ & $\begin{array}{l}\text { - Lack of scheduled teaching for library } \\
\text { instructions } \\
\text { - } \quad \text { Lack of support from teachers } \\
\text { - } \quad \text { Lack of staff } \\
\text { - } \\
\text { Insufficient professional development } \\
\text { external organization when offered in } \\
\text { after school hours }\end{array}$ \\
\hline
\end{tabular}

Study participants were asked about the barriers that may block the full implementation of their school library programs in their schools, particularly the instructional components. It is interesting that primary school librarians in Croatia have not mentioned any serious barrier and this finding confirms the result from the study by Zorica and Dukic (2016). For primary school librarians in Hong Kong the major barrier is the lack of scheduled teaching and not being recognized as teachers by the school principal. The lack of scheduled teaching for library instruction is the main obstacle for secondary school librarians both in Croatia and in Hong Kong. School librarians in secondary school struggle to find teaching time in the school busy schedule and have to negotiate with subject teachers to find some teaching slots for library lessons.

\section{CONCLUSIONS AND RECOMMENDATIONS}

The findings of this study indicate that school librarians in Croatia and Hong Kong are well aware of educational role of school libraries and that they actively support students' learning through their library programs. These programs are mainly focused on motivating students for reading and on library instruction involving enhancement of students' information literacy and research capabilities.

Reading programs in school libraries in Croatia and Hong Kong are rich with various readingrelated activities and are often organized in collaboration with school teachers. Croatian and Hong Kong school librarians collaborate well with other school librarians in their local areas and run together various reading-related projects.

In addition, school librarians in Croatia broaden their reading programs through collaboration with public libraries, museums and many other cultural organizations.

School librarians in Hong Kong widely apply information technologies to motivate students' reading and provide access to rich collections of e-books.

Library instruction programs are performed by school librarians on both locations according to their specific circumstances and defined programs. Primary school librarians from Croatia extend their regular information literacy programs to some other useful topics such as entrepreneurship and financial literacy. School librarians in Hong Kong pay significantly more attention to teaching students how to retrieve and access various electronic resources from their rich digital collections.

Many library programs and activities, both in Croatia and Hong Kong, are performed in collaboration with school teachers, although this collaboration is not always on a regular basis and not involving all teachers from the school. School librarians also collaborate with their colleagues in other schools, with public libraries and some other organizations. 
For most school librarians a major barrier to running a successful information literacy program is their not being included in the official teaching schedule. This barrier might be overcome to some extent by developing and applying e-learning strategies.

Based on the finding of this study it can be concluded that school librarians, both in Croatia and

Hong Kong, provide a significant input to school teaching and learning and that their library programs transcend the library walls and often cross even the school borders.

There are several potential benefits of this study. For school librarians it may be useful to gain insight into library programs and activities performed by school librarians from other countries and get ideas for enhancing their own library programs. For researchers in school librarianship the results of this study may help to plan some further comparative studies on school library programs. Finally, the work on this project was new and valuable experience for researchers from two very distant parts of the world to work together as a virtual team and learn from each other.

\section{REFERENCES}

Braun, V., \& Clarke, V. (2006) Using thematic analysis in psychology. Qualitative Research in Psychology, 3(2), 77-101.

Cheng, P. (2012). Perceiving usefulness: The perception of users on school libraries and librarians in Hong Kong. Doctoral dissertation, Charles Sturt University, Wagga Wagga, Australia.

Chu, K. W. S., Tse, S. K., Loh, E. K. Y., Chow, K., Fung, H. F., \& Ng, H. W. R. (2008). Primary four students' development of reading ability through inquiry-based learning projects. In International Association of School Librarianship. Selected Papers from the 37th Annual Conference. International Association of School Librarianship.

Cooper, O. P., \& Bray, M. (2011). School library media specialist - teacher collaborations: Characteristics, challenges, opportunities. TechTrends, 55(4), 48-54.

Halverson, R., \& Smith, A. (2009). How new technologies have (and have not) changed teaching and learning in schools. Journal of Computing in Teacher Education, 26(2), 49-54.

Haycock, K. (2007). Collaboration: Critical success factors for student learning. School Libraries Worldwide, 13(1), 25-35.

International Federation of Library Associations (2015). IFLA School Library Guidance, $2^{\text {nd }}$ revised edition. Den Haag Netherlands: International Federation of Library Associations and Institutions. Retrieved March 15, 2017 from https://www.ifla.org/publications/node/9512

Ip, K., Chu, S. K.W. \& Sit, D. K. N. (2008). Primary students' reading habits of printed and e-books. Paper presented at the IASL Conference [CD-ROM], University of California at Berkeley..

Johnston, M. P. (2012). School librarians as technology integration leaders: Enablers and barriers to leadership enactment. School Library Research, 15(1).

Jones, T. \& Brown, C. (2011). Reading engagement: a comparison between e-books and traditional print books in an elementary classroom. International Journal of Instruction, 4(2), 5-22.

Lai, J., \& Wei, D. (2013) Collaboration between teachers and librarians for information literacy curriculum: A case study of a Hong Kong secondary school. Journal of Studies in Education, 3(3), 75-91.

Lo, P., Dukic, D., Chen, J., Youn, Y, Hirakue, Y., Nakashima, M., \& Yang, G. (2014a). Attitudes and self perceptions of school librarians in relation to their professional practices: a comparative study between Hong Kong, Shanghai, South Korea, Taipei, and Japan. School Libraries Worldwide, 20(1), 52-69.

Lo, P. , Chen, J. , Dukic, Z. , Youn, Y.-R. , Hirakue, Y. , Nakashima, M., \& Yang, G. (2014b). The roles of the school librarians as information literacy specialists: a comparative study between Hong Kong, Shanghai, South Korea, Taipei and Japan. New Library World, 115(7/8), 314-338.

Lupton, M. (2016). Adding Value: Principals' Perceptions of the Role of the Teacher-Librarian. School Libraries Worldwide, 22(1), 49-61.

Shu, C., Chu, S.K.W., \& Wu, W.W.Y. (2014). Rethinking the educational role of school librarians. Paper presented at the Fifth World Chinese School Librarians' Forum, Hong Kong. 
Ministarstvo Prosvjete i Športa Republike Hrvatske (2000). Standard za školske knjižnice. Narodne novine, 34. Retrieved March 15, 2017 from http://narodnenovine.nn.hr/clanci/sluzbeni/2000_03_34_698.html

Stričević, I. (2008). Školske knjižnice i partnerstvo u zajednici. XX Proljetna škola školskih knjižničara Republike Hrvatske: Suradnja u informacijskom društvu - s obzirom na potrebe školskog knjižničarstva (Str. 129-133). Mićanović, M. (Ur.). Zagreb: Agencija za odgoj i obrazovanje.

Udina, K. (2014). Emerging technologies or technophobia in school libraries survey: technology and learning in school libraries in Croatia. Information Literacy. Lifelong Learning and Digital Citizenship in the 21st Century. Second European Conference, ECIL 2014, Dubrovnik, Croatia. Proceedings (pp. 291-296). S. Kurbanoğlu, S. Špiranec, E. Grassian, D. Mizrachi and R. Catts (Eds.). Cham, Switzerland: Springer.

Warning, P., Chan, R.C.H., Ma, B.H.Y., Chu, S.K.W., \& Wu, W.W.Y. (2013). The educational roles of primary and secondary school teacher-librarians in Hong Kong. Paper presented at the 42th International Association of School Librarianship 2013 Conference, Bali, Indonesia.

Wine, L.D. (2016). School librarians as technology leaders: an evolution in practice. Journal of Education for Library and Information Science, 57(2), 207-220. 